$$
\begin{aligned}
& \text { aus Bedingungs- direkte Rechnung gibt } \\
& \text { gleichungen abweichend hierzu } \\
& \cos { }^{\circ} \mathrm{d} \alpha^{\prime \prime} \mathrm{d} \delta^{\prime \prime} \quad \cos 8 \mathrm{~d} \alpha^{\prime \prime} \mathrm{d} 8^{\prime \prime} \\
& \text { 1919 VI }+0.9+3.7+1.0 \\
& \mathrm{VII}+0 . \mathrm{I}+8.0 \\
& \text { VIII }-4.3+9.2 \\
& \mathrm{IX}+9.3-\mathrm{I} 4.2+9.2 \\
& \mathrm{X}-6.6-19.6-19.5 \\
& 1847 I+17.6+18.7+17.5+18.6 \\
& \text { II }-16.6-7.6 \\
& \text { III }-10.6+8.0
\end{aligned}
$$

mit $\mu= \pm 1 \%$.

Diese Darstellung ist im Hinblick darauf, daß die Beobachtungen unter ungünstigsten Umständen zu leiden hatten,

Berlin-Charlottenburg, 192 I Juli. durchaus befriedigend, zumal auch die Verteilung der Fehler eine wesentlich bessere geworden ist.

8. Schlußbemerkungen. Eine weitergehende Verbindung beider Erscheinungen müßte eine vollständige Neubearbeitung der Erscheinung 1847 und eine Wiederholung der Störungsrechnungen zwischen den Peribeldurchgängen mit mehrmaligem Übergang auf oskulierende Elemente zur Grundlage haben. Die diesbezïgl. Rechnungen und die weitere Verfolgung des Bahncharakters beabsichtige ich durchzuführen, sobald anzunehmen ist, $\mathrm{daß}$ sämtliche erlangten Ortsbestimmungen veröffentlicht worden sind. Die endguiltigen Ergebnisse werde ich alsdann zusammen mit dem Beobachtungsmaterial in angemessener Ausführlichkeit publizieren.

P. Duckert.

\title{
Rare apparitions of the Zodiacal Light.
}

In the evening of the $26^{\text {th }}$ of December, 1921 , when I was staying at Okayama,

Longitude $=133^{\circ} 56^{\prime} \mathrm{E}$ of Gr., Latitude $=34^{\circ} 40^{\prime} \mathrm{N}$, I saw a splendid apparition of the Zodiacal Light standing on the western horizon. The width was rather narrow, being scarcely over twenty degrees even in its foot. The length, however, was enormous, and it could be traced easily up to the constellation of Aries. The entire form was rightly straight, and that along the ecliptic. The luminosity was condensing toward its central line, and the brightest part of it was estimated to be as bright as the brightest part of the Milky Way, or more. As the weather was very clear and the Milky Way was in full view, more or less parallel to the above Zodiacal Light, the night view of the heaven was very beautiful.

The next day was clouded. In the morning of the $28^{\text {th }}$, following, when I was with several friends for observing the planets, I again caught sight of the Zodiacal Light in the eastern part of the heaven. This time, it was low in height reaching only the boundary of Virgo. The brightness was less than the former one, and was of an ordinary display seen in the usual autumnal morning. But its base on the horizon was as wide as forty degrees, so that the whole appearance was nearly that of a regular triangle.

In the night of the $30^{\text {th }}$, after I came back to home in Kyoto, I received a telegram from Mr. $K$. Misawa, living at Suwa, Nagano-prefecture, about $270 \mathrm{~km} \mathrm{ENE}$ of Kyoto. His telegram said that he saw an unusual appearance of the Zodiacal Light in the evening of the $30^{\text {th }}$. Here I knew that the apparitions-seen at Okayama were of some cosmical nature, not limitted by localities and others. Yesterday, 1 received a letter from Mr. Misawa, writing very fully the observations made by himself and some other ones with him there. According to the letter, the Suwa observers saw the rare phenomenon in four evenings in the latter part of December, that is on the $25^{\text {th }}, 27^{\text {th }}, 30^{\text {th }}$, and the $3 \mathrm{I}^{\text {st }}$. And his words and the accompanying sketches show that the form of the luminosity was much elongated in the early part of the epoch, stretching more than one hundred degrees of arc. The brightness was also enormous, and one of the observers who had a keen sight could see the light safely under a street lamp. Gradually, however, the form of the Zodiacal Light shortened toward the end of the month, and so was the brightness.

Now, I see that our observations are fortunately continuous for a week. Within these days, the form and the brightness of the Zodiacal Light changed pretty rapidly, both downward. But yet, in the nearest two evenings, that is, in the $4^{\text {th }}$ and $5^{\text {th }}$, inst., I myself could see the luminosity, more or less safely even through the moon light!

We do not know the date of the beginning of the phenomena. When we detected them for the first time, either at Suwa or Okayama, it was. perhaps near the climax of the displays. Probably, the European and American observers could see the same light in the same epoch, and that more perfectly.

$$
\text { Kyoto, Imperial University Observatory, } 1922 \text { January } 5 .
$$

Issei Yamamoto.

\section{Die großen Sonnenflecken Mitte Mai und Anfang Juni 1921. Von Nils Tamm.}

Die Gruppe von drei Flecken, die Mitte Mai nabe dem Zentrum der Sonnenscheibe passierten, hatten eine interessante äquatoreale Lage. Messungen an einer photographischen Platte (Sonnenbildradius $=37.9 \mathrm{~mm}$ ), am 14 . Mai $15^{\mathrm{h}} \cdot 25$ M.E.Z. aufgenommen, geben die folgenden heliographischen Koordinaten:

Als die Flecken Anfang Juni wieder am Ostrande zu erwarten waren, zeigte sich nur ein einziger Fleck. Nach Einzeichnungen desselben auf einem Projektionsbild der Sonne (Radius $=100 \mathrm{~mm}$ ) sind die Koordinaten gemessen und berechnet worden: 